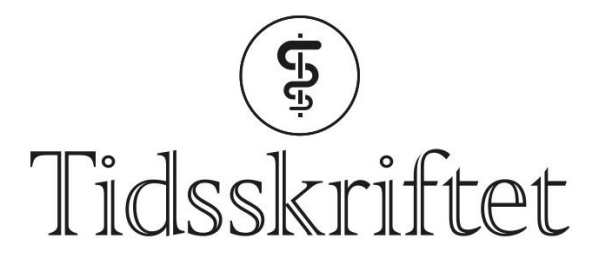

DEN NORSKE LEGEFORENING

\title{
Studenter spiser matpakken blant lik og dyr
}

TIDLIGERE I TIDSSKRIFTET

SYNNE LOFSTAD

E-post: synne.lofstad@hotmail.com Redaksjonssjef i Æsculap

Studentvelferd har naturlig nok ofte vært et tema i Æsculap. I 1985 var studentenes kantinefasiliteter i Bergen oppe til diskusjon, og Studentenes Kantine-Komite (SKK) redegjør i Æsculaps utgave 4 for sakens dramatiske utvikling (Æsculap 1985; 65(4): 6).

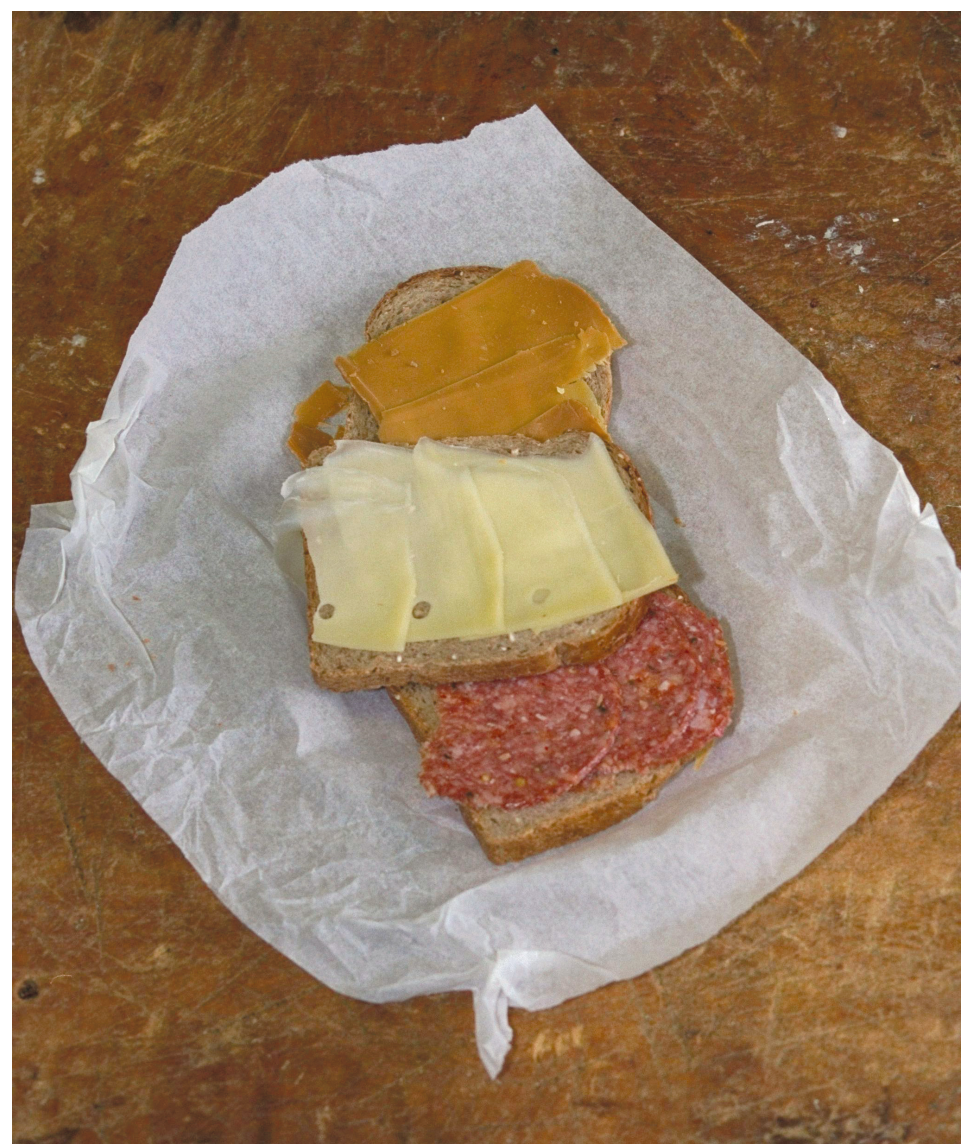

Illustrasjon:VG/NTB Scanpix

\section{Kantineproblemer}

Medisinstudentene ved PKI (De prekliniske institutter, red.anm.) i Bergen har idag ikke noe spiserom. En student tilbringer opptil 12 timer av sin dag på PKI, og naturlig nok føler vi 
behov for og har lenge arbeidet for et skikkelig kantinetilbud med middagsservering. Kantinen er som kjent et samlingspunkt og bidrar til å skape et miljø blant oss studenter.

PKI i Bergen ble bygget i 1966. Det var planlagt en etasje med studentkantine, men $\emptyset$ konomien ble trang, og planene følgelig ikke gjennomført. Siden dengang har vi studenter vært "gjester» i de ansattes spiserom, hvor studentsamskipnaden har drevet kantine i en rekke år. I lunsjtiden er det særlig trangt om saligheten og mellom kl.10.30 og 12.30 har studenter ingen adgang. Vi er derfor henvist til å spise vår matpakke i trekkfulle korridorer, mens de ansatte nyter godt av vår kantinedrift og hyggelige kantinedame! Adgangsforbudet har ikke vært overholdt av studentene. Dette har vakt adskillig harme blant de ansatte, med påfølgende kjefting og sammenstøt mellom de to gruppene.

Studentenes kantinekomite SKK ble dannet i forsøket på å finne en løsning på kantineproblemet. Komiteen er innforstått med ansattes rett til spiserom. Spørsmålet blir om studenter også bør ha rett til spiserom. Vi kontaktet såvel Arbeidstilsynet, Helserådet og Universitetet for å kartlegge våre rettigheter. Men alle svar er negative, det er dessverre ingen som har ansvar for å gi oss tilfredsstillende kantineforhold. Universitetet mener de har oppfylt sine krav om at SIB driver studentby med kantine ikke langt fra PKI. Men våre dager er belagt med forelesninger fra 08.15 til 15.0o, og da er det innlysende at vi har behov for kantine på vår «arbeidsplass».

Forskjellige grupperinger har siden -79 arbeidet med en rekke forslag til omdisponering av lokaler på PKI for om mulig å frigjøre plass til kantinedrift. Diverse forslag har hittil blitt forkastet etter at de har vist seg lite hensiktsmessige.

Da ingen utspill førte frem, besluttet vi å gå til Bergens tidende med saken. Hensikten med artikkelen var å påpeke at studentene ikke har rettigheter til et respektabelt spisested. At oppslaget ble tendensiøst og sensasjonspreget er noe vi tar avstand fra og har beklaget. Komiteens kritikk til BT ble avvist med at dette lå utenfor vårt innflytelsesområde.

Særlig overskriften «Studenter spiser matpakken blant lik og dyr» utløste et ramaskrik blant PKIs ansatte. Saken er nå til behandling i det akademiske kollegium. SKK ble av styrer på anatomisk institutt anklaget for brudd på taushetsløftet. Hvilket skulle bety utvisning fra studiet. Pr. idag har studentene 12t. arbeidsdag, men ingen arbeidsgiver med ansvar for vår velferd. Det er ikke avsatt plass til oss innenfor paragraframmene. Vi kommer i gruppe med barn i grunnskolen og kan henvises til å spise matpakken på gårdsplassen! PKI er dessverre intet enestående eksempel, studenter ved andre studiesteder har lignende forhold.

Studentenes Kantine-Komite, Bergen

Publisert: 29. juni 2020. Tidsskr Nor Legeforen. DOI: 10.4045/tidsskr.20.0465

(C) Tidsskrift for Den norske legeforening 2020. Lastet ned fra tidsskriftet.no 